\title{
APPLICATION OF FRACTAL CONCEPT IN MATERIAL BATIK DEVELOPMENT BASED ON WOLFRAMS MATHEMATICA
}

\author{
Saiful Marom \\ Department of Mathematic Education \\ IAIN Salatiga \\ Saifulmarom2704@gmail.com
}

\begin{abstract}
The geometry concept has been developed rapidly, one of them is about fractal geometry. In fractal geometry concept, it has been discussed about shapes which have fractal dimension characteristics. In fractal geometry concept, it would resulted in a look like irregular shape. But if it had been observed closer, it would found a regular shape. Self-similarity is a characteristic in fractal geometry when diferent magnifications was found. In fractal concept, a pattern would be obtained from a function itteration by an infinite repetition. One of fractal geometry application is in batik design fabrications. This idea based on equality dimension, that is both of them is in fractal dimension. In fractal geometry, it will result in a specific design by itterated function using Wolframs a program.
\end{abstract}

Key Word : Fractal Geometry, Design of Batik, Wolframs Mathematica

\begin{abstract}
Abstrak. Berkembangnya konsep geometri sangat pesat diantaranya adalah mengenai geometri fraktal. Dalam konsep geometri fraktal dikaji mengenai bentukbentuk yang memenuhi sifat-sifat dimensi fraktal. Dalam konsep geometri fraktal banyak dihasilkan suatu bentuk yang terlihat tidak beraturan akan tetapi ketika diamati lebih jauh maka ada suatu bentuk keteraturan didalamnya. Self-similarity adalah salah satu sifat pada geometri fraktal pada saat terjadi pembesaran yang berbeda. Pada konsep fraktal, dapat diperoleh suatu pola yang didapatkan dari hasil iterasi suatu fungsi tertentu dengan perulangan tak terhingga. Banyak aplikasi geometri fraktal, salah satunya untuk pengembangan kebudayaan yaitu dalam pembentukan motif batik. Ide pembentukan motif batik ini didasarkan karena kesamaan dimensi yaitu sama-sama dalam dimensi fraktal. Pada geometri fraktal ini akan diperoleh suatu motif yang khas yaitu dengan mengiterasikan suatu fungsi tertentu dengan berbatuan program Wolframs Mathematica.
\end{abstract}

Kata Kunci : Geometri Fraktal, Motif batik, Wolframs Mathematica. 


\section{Pendahuluan}

Mata pencaharian sebagian besar masyarakat Kota Pekalongan ada pada sektor swasta baik di bidang industri, perdagangan barang dan jasa. Khususnya sektor industri dengan komoditas berupa Batik, tenun, garment, serta industri minuman berupa teh.

Sektor industri dan perdagangan tersebut sangat berpengaruh terhadap pertumbuhan ekonomi lokal kota Pekalongan salah satu barometer pertumbuhan ekonomi ada pada sektor industri batik dan turunannya sehingga Kota Pekalongan di kenal oleh masyarakat industri sebagai kota batik.

Industri batik menjadi industri yang paling besar di Kota Pekalongan jumlah UKMK di Kota Pekalongan menurut data tahun 2010 sebanyak 10.700 unit, karena batik merupakan produk budaya Indonesia yang sangat unik dan merupakan kekayaan budaya yang harus dilestarikan dan dibudidayakan. Selain itu, batik juga merupakan salah satu solusi potensial untuk mendongkrak devisa negara melalui revitalisasi industri kecil dan menengah. Hingga kini batik digunakan sebagai pakaian yang sangat eksotis. Khususnya kerena motifnya yang unik dan beragam baik itu di mata masyarakat pribumi sendiri ataupun pendatang asing.

Dalam proses pembuatannya, Batik ternyata memakan proses yang cukup lama dan rumit. Mulai dari pemilihan kain yang bagus dan sesuai, kemudian pewarnaan batik, dan pelukisan seni batik baik menggunakan canting cap maupun tangan.

Keunikan seni batik sendiri dapat dilihat motifnya yang beraneka ragam mulai dari motif yang bernuansa klasik hingga modern. Definisi dari motif adalah corakcorak hiasan yang digunakan dalam proses melukis atau menerapkan batik. Bentuknya berupa dua motif bentuk utama yaitu, motif organik dan geomatrik. Motif organik merupakan motif yang berunsurkan alam seperti tumbuhantumbuhan, hewan dll. Sedangkan motif geomatrik ada beberapa macam seperti pucuk rebung dan motif bunga kotak bercampur.

Berdasarkan Forum Discussion Group (FGD) Persoalan pertama yang dihadapi oleh pengusaha batik dan belum kunjung selesai diperjuangkan adalah mengajak kaum muda sebagai salah komponen pasar dan penerus budaya bangsa untuk mencintai batik. Ini adalah sebuah tantangan bagi masyarakat perbatikan Pekalongan untuk mencari trik bagaimana anak muda mulai mencintai batik. Jika memang mau melihat batik sebagai sebuah masa depan, maka segmentasi anak muda ini harus jadi perhatian. Para perajin batik hendaknya mulai memikirkan motif-motif yang bisa dekat ke anak muda.

Fraktal adalah merupakan suatu konsep geometris yang kasar dalam berbagai skala dan akan nampak seperti dapat dipartisi dengan cara yang tidak teratur. Dalam konsep fraktal sebuah bentuk tertentu dapat dipecah menjadi beberapa bagian yang semuanya mempunyai kemiripan dengan sumbernya. Konsep fraktal dikembangkan pada tahun 1975 oleh Benoit Mandelbrot, dalam tulisannya yang berjudul "A Theory of Fractal Set". Asal kata fraktal diperoleh dari bahasa latinnya 
frangere yang mempunyai makna terbelah menjadi beberapa fragmen dengan tingkat ketidakteraturannya sangat tinggi.

Berdasarkan hasil pemaparan sebelumnya maka penulis mengaitkan kesamaan antara dimensi motif batik dengan dimensi dalam geometri fraktal sehingga disini penulis tertarik untuk mengkaji mengenai pengembangan desain motif batik menggunakan konsep fraktal berbantuan wolframs mathematica.

\section{Pembahasan}

\subsection{Konsep Fraktal}

Dalam ilmu matematika, konsep fraktal adalah suatu bentuk cabang geometri kompleks yang pada umumnya mempunyai dimensi yang dikenal dengan dimensi fraktal atau suatu dimensi pecahan. Konsep fraktal ini pada tahun 1918 diperkenalkan oleh Felix Housdorff. Pada geometri fraktal ini mempunyai suatu sifat yakni menyerupai diri sendiri atau biasa dikenal dengan self similar, sifat ini mempunyai makna bahwa setiap bagian kecil dalam geometri fraktal dapat dilihat sebagai bagian dari replikasi dengan skala kecil dari bentuk keseluruhan.

Dalam konsep fraktal berbeda dengan bentuk klasisk sederhana pada geometri Euclid yakni seperti lingkaran, bola atau yang lainnya. Dalam menggunakan konsep fraktal ini kita dapat menjelaskan banyak obyek yang mempunyai bentu yang tidak beraturan seperti fenomena alam yang secara spasial tidak dalam kondisi seragam. Misalnya adalah sebuah gambar pantai atau sebuah gunung. Dalam tulisannya Mandelbrot menjelaskan bahwa setiap objek alam berperilaku sebagai fraktal dalam hal ini merupakan hasil kerja gaya yang sama yang bekerja pada berbagai tingkatan skala pada suatu objek sehingga mengakibatkan iterasi atau pengulangan bentuk dasar (fractal seed atau fractal generator) yang hasilnya menyatu dalam satu objek yang bersangkutan. Proses itu dikenal sebagai proses self similiarity yang bersifat scale invariant: artinya diamati dengan skala berapapun bentuk geometrinya maupun dimensinya tetap sama dengan benih fraktalnya.

Fractal bermula dari chaos yaitu geometri yang memiliki sifat acak (random) , ganguan (noise) atau tidak teratur (chaotic) konsep fractal dapat menguraikan sifat fisis yang rumit menjadi elemen yang lebih sederhana. Proses yang lama kelamaan membentuk suatu keteraturan tertentu yaitu self-similarity, self-affinity, self inverse dan self squaring yang merupakan konsep dasar dari geometri fraktal, sifat yang berupa self similarity menunjukkan bahwa fraktal terdiri dari bagian -bagaian yang berbenruk serupa satu sama lain. Self affinity menggambarkan bahwa fractal disusun atas bagian-bagain geometri yang saling terangkai satu sama lain, self inverse artinya terdapat terdapat suatu bagaian pada geometri fractal yang merupakan susunan terbalik dari susunan lainnya. Sedangakan self-squaring dapat di artikan bahwa suatu bentuk geometi fractal merupakan peningkatan kerumitan dari bagaian sebelumnya atau secara matematis di sebut pengkuadratan. 


\subsection{Bentuk-bentuk Fraktal}

Ada beberapa bentuk dari fraktal salah satunya adalah segitiga Sierpinski atau Sierpinski triangel yang ditemukan oleh Waclaw Sierpinski dengan membagi sebuah segitiga sama sisi yang dipartisi menjadi empat belahan dengan ukuran yang sama. Selanjutnya Waclaw Sierpinski juga membagi untuk dengan jenis segitiga yang lain yang lebih kecil. Jika pembagian dilanjutkan sampay tak terhingga maka untuk membayangkan bentuk detailnya, jika salah satu bagian yang gelap diambil dan kemudian diperbesar mendekati tak berhingga, maka akan didapatkan bentuk segitiga seperti bentuk keseluruhannya.

Selain cara sebelumnya kita juga dapat membuat segitiga Sierspinski dengan langkah awal membuat segitiga, kemudian segitiga ini dilubangi di tengahtengahnya dan di ketiga bagian sudut-sudutnya dengan segitiga yang berukuran lebih kecil. Selanjutnya proses pelubangan yang sama untuk setiap sisa segitiga yang masih berisi diulangi terus hingga jumlah yang tak berhingga. Tentu saja proses semacam ini akan terasa sulit jika dikerjakan secara manual atau hanya dengan menggunakan goresan tangan, biasanya bentuk fraktal diperoleh dengan menggunakan bantuan komputer. Penulis akan memberika ilustrasi secara matematis dan dengan menggunakan program Wolframs Mathematica

Dipunyai W $\left(\begin{array}{l}\mathrm{x} \\ \mathrm{y}\end{array}\right)=\left(\begin{array}{cc}\frac{1}{2} & 0 \\ 0 & \frac{1}{2}\end{array}\right)\left(\begin{array}{l}\mathrm{x} \\ \mathrm{y}\end{array}\right)+\left(\begin{array}{l}\frac{1}{2} \\ 0\end{array}\right)$

Akan ditunjukkan $A_{n}=W^{\text {on }}\left(A_{0}\right)$ untuk $n=1,2, \ldots$

$$
\begin{aligned}
& A_{0}=(0,1) \\
& A_{1}=W^{01}\left(A_{0}\right)=W\left(\begin{array}{l}
0 \\
1
\end{array}\right)=\left(\begin{array}{ll}
\frac{1}{2} & 0 \\
0 & \frac{1}{2}
\end{array}\right)\left(\begin{array}{l}
0 \\
1
\end{array}\right)+\left(\begin{array}{l}
\frac{1}{2} \\
0
\end{array}\right)=\left(\begin{array}{l}
\frac{1}{2} \\
\frac{1}{2}
\end{array}\right) \\
& A_{2}=W^{02}\left(A_{0}\right)=W\left(W\left(A_{0}\right)\right)=W\left(A_{1}\right)=W\left(\begin{array}{l}
\frac{1}{2} \\
\frac{1}{2}
\end{array}\right)=\left(\begin{array}{ll}
\frac{1}{2} & 0 \\
0 & \frac{1}{2}
\end{array}\right)\left(\begin{array}{l}
\frac{1}{2} \\
\frac{1}{2}
\end{array}\right)+\left(\begin{array}{l}
\frac{1}{2} \\
0
\end{array}\right)=\left(\begin{array}{l}
\frac{3}{4} \\
\frac{1}{4}
\end{array}\right) \\
& A_{3}=W^{03}\left(A_{0}\right)=W\left(W\left(W\left(A_{0}\right)\right)\right)=W\left(A_{2}\right)=W\left(\begin{array}{l}
\frac{3}{4} \\
\frac{1}{4}
\end{array}\right)=\left(\begin{array}{ll}
\frac{1}{2} & 0 \\
0 & \frac{1}{2}
\end{array}\right)\left(\begin{array}{l}
\frac{3}{4} \\
\frac{1}{4}
\end{array}\right)+\left(\begin{array}{l}
\frac{1}{2} \\
0
\end{array}\right)=\left(\begin{array}{l}
\frac{7}{8} \\
\frac{1}{8}
\end{array}\right)
\end{aligned}
$$




$$
A_{4}=W^{04}\left(A_{0}\right)=W\left(W\left(W\left(W\left(A_{0}\right)\right)\right)\right)=W\left(A_{3}\right)=W 4\left(\begin{array}{l}
\frac{7}{8} \\
\frac{1}{8}
\end{array}\right)=\left(\begin{array}{cc}
\frac{1}{2} & 0 \\
0 & \frac{1}{2}
\end{array}\right)\left(\begin{array}{l}
\frac{7}{8} \\
\frac{1}{8}
\end{array}\right)+\left(\begin{array}{l}
\frac{1}{2} \\
0
\end{array}\right)=\left(\begin{array}{c}
\frac{15}{16} \\
\frac{1}{16}
\end{array}\right)
$$

Dari iterasi sebelumnya dilanjutkan sampai n sehingga secara umum diperoleh $\mathrm{A}_{\mathrm{n}}=\mathrm{W}^{\text {on }}\left(\mathrm{A}_{0}\right)$ for $\mathrm{n}=1,2, \ldots$. Karena $\mathrm{w}_{\mathrm{i}}(\mathrm{A}) \in \mathrm{H}\left(R^{2}\right) \forall \mathrm{i}$ maka $\bigcup_{\mathrm{i}=1}^{\infty} \mathrm{w}_{\mathrm{i}}(\mathrm{A}) \in \mathrm{H} \quad\left(R^{2}\right)$, Jadi diperoleh $\mathrm{W}(\mathrm{A})=\bigcup_{\mathrm{i}=1}^{\infty} \mathrm{w}_{\mathrm{i}}(\mathrm{A})$. Sehingga ditemuakan $W: \mathrm{H}\left(R^{2}\right) \rightarrow \mathrm{H}\left(R^{2}\right)$.

Dengan menggunakan Program Wolframs Mathematica diperoleh :

$$
\begin{aligned}
& \text { w1 }\left[\left\{x_{-}, y_{-}\right\}\right]:=\{0.5 x+0.5,0.5 y\} \\
& \text { w2 }\left[\left\{x_{-}, y_{-}\right\}\right]:=\left\{0.5 x_{1}, 0.5 y+0.5\right\} \\
& \text { w3 }\left[\left\{x_{-}, y_{-}\right\}\right]:=\left\{0.5 x_{1}, 0.5 y\right\} \\
& \text { Triangle }\left[n_{-},\left\{\left\{x_{1}, y^{1} \_\right\},\left\{x_{2}, y^{2} \_\right\},\left\{x_{3}, y^{3} \_\right\}\right]:=\text {Nest }[\text { Flatten }\right.
\end{aligned}
$$
$[$ Table $[\{\{\mathrm{w} 1[\#[[i, 1]]], w 1[\#[[i, 2]]], w 1[\#[[i, 3]]]\},\{w 2[\#[[i$, $1]]], w 2[\#[[i, 2]]], w 2[\#[[i, 3]]]\},\{w 3[\#[[i, 1]]], w 3[\#[[i, 2]]]$ ,w3 $[\#[[i, 3]]]\}\},\{i$, Length $[\#]\}], 1] \&,\{\{\{x 1, y 1\},\{x 2, y 2\},\{x 3, y$ 3\} \} \}, n] ;

Manipulate $[$ vertices=Triangle $[n,\{\{0,0\},\{0,1\},\{1,0\}\}]$; Graphics $[\{B]$ ue, Polygon [vertices] $\}],\{n, 0,7,1\}]$

Berikut hasil running program wolframs yang dibuat diperoleh :

Untuk $\mathrm{n}=0$

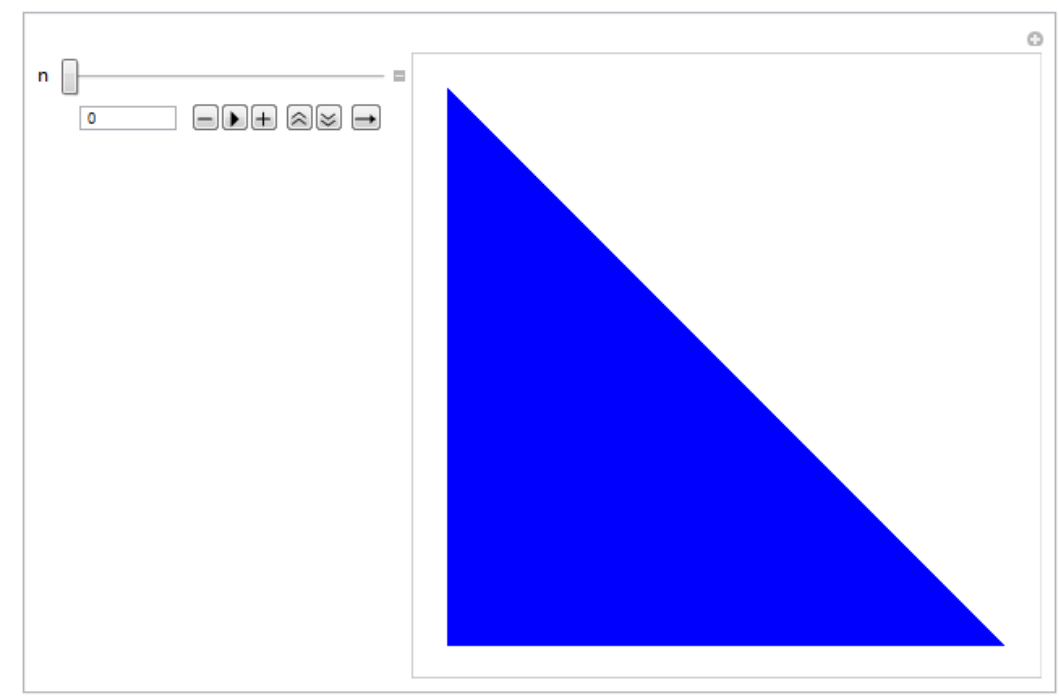


Untuk $\mathrm{n}=1$

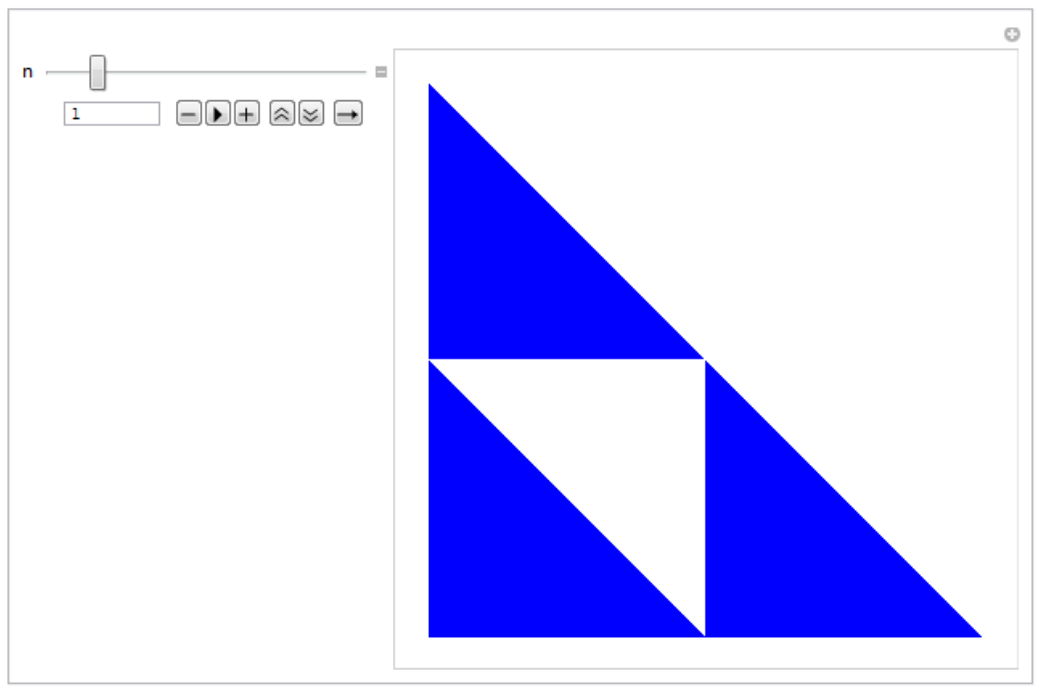

Untuk $\mathrm{n}=2$

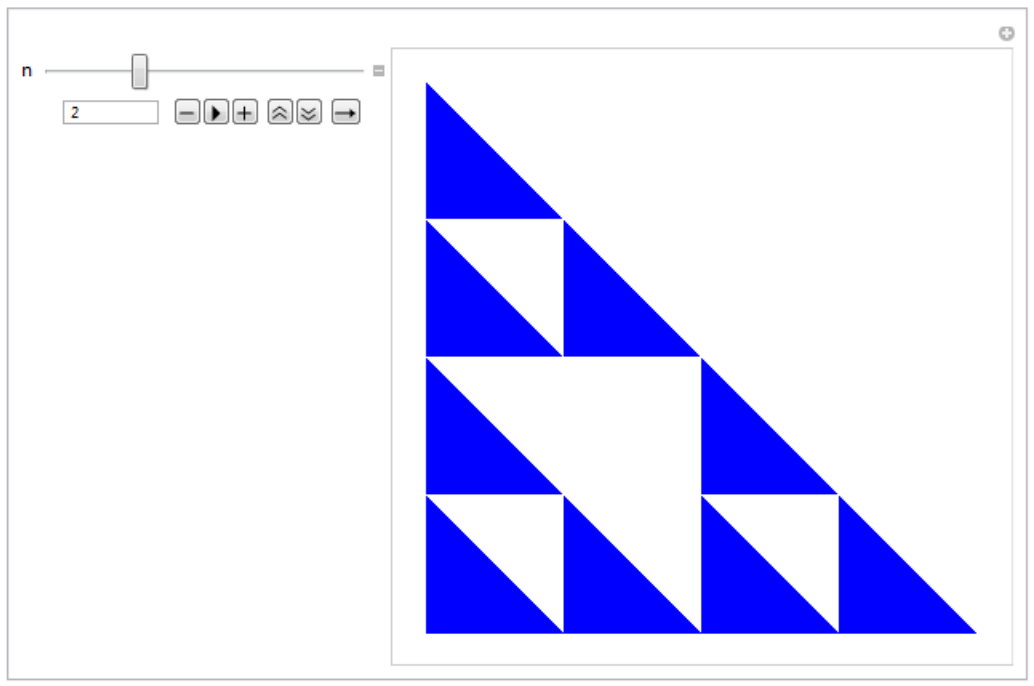


Untuk $\mathrm{n}=3$

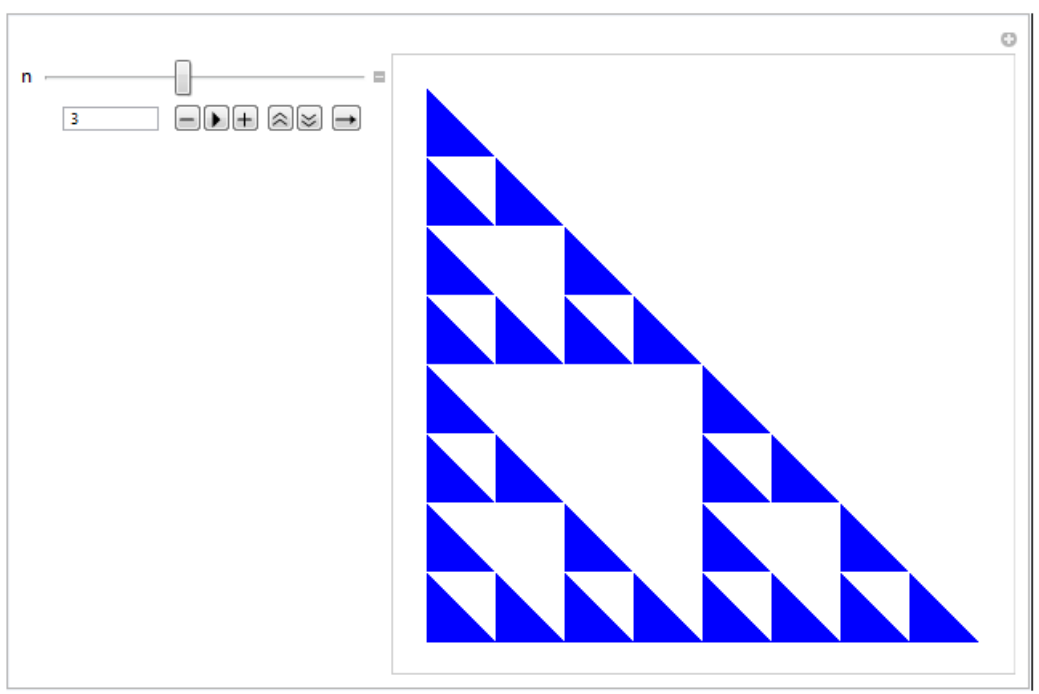

Dan seterusnya untuk $\mathrm{n}=5$ diperoleh :

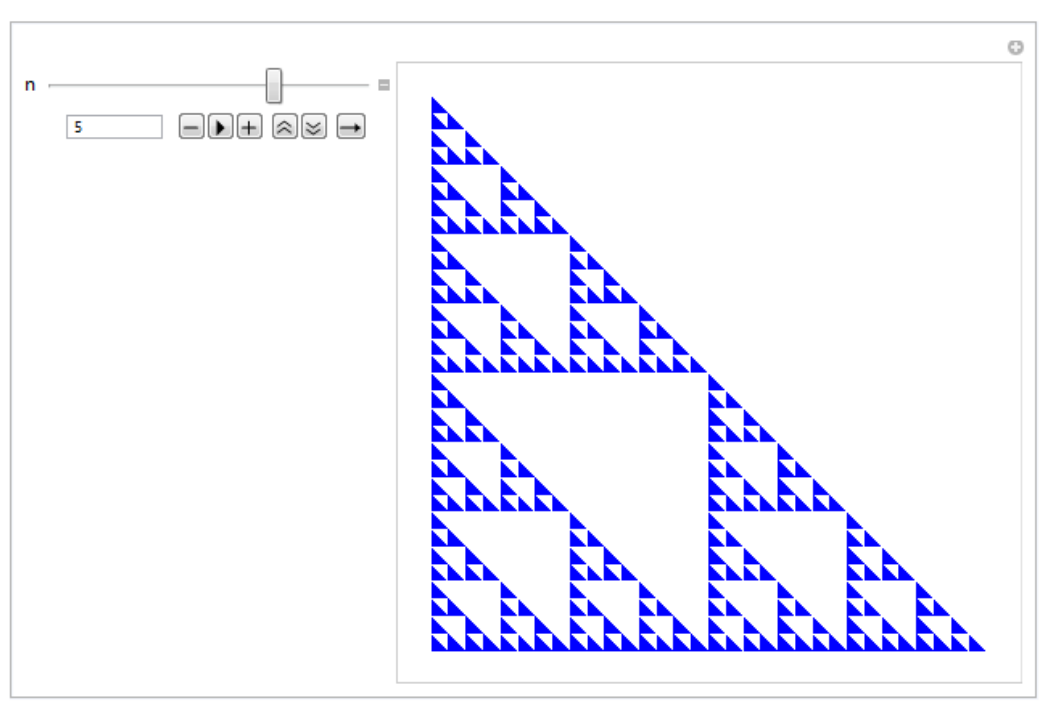

Selanjutnya akan diberikan program wolframs mathematica yang lain yakni karpet Sirpienski :

$$
\begin{aligned}
& \text { w1 }\left[\left\{x_{-}, y_{-}\right\}\right]:=\{1 / 3 x, 1 / 3 y\} \\
& \text { w2 }\left[\left\{x_{-}, y_{-}\right\}\right]:=\{1 / 3 x, 1 / 3 y+1 / 3\} \\
& \text { w3 }\left[\left\{x_{-}, y_{-}\right\}\right]:=\{1 / 3 x, 1 / 3 y+2 / 3\} \\
& \text { w4 }\left[\left\{x_{-}, y_{-}\right\}\right]:=\{1 / 3 x+1 / 3,1 / 3 y+2 / 3\} \\
& \text { w5 }\left[\left\{x_{-}, y_{-}\right\}\right]:=\{1 / 3 x+2 / 3,1 / 3 y+2 / 3\} \\
& \text { w6 }\left[\left\{x_{-}, y_{-}\right\}\right]:=\{1 / 3 x+2 / 3,1 / 3 y+1 / 3\} \\
& \text { w7 }\left[\left\{x_{-}, y_{-}\right\}\right]:=\{1 / 3 x+2 / 3,1 / 3 y\} \\
& \text { w8 }\left[\left\{x_{-}, y_{-}\right\}\right]:=\{1 / 3 x+1 / 3,1 / 3 y\}
\end{aligned}
$$

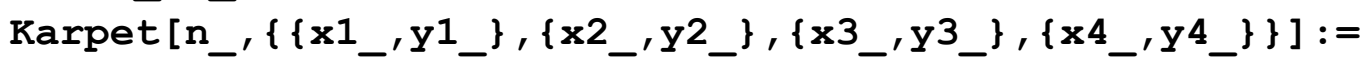

$$
\begin{aligned}
& \frac{\text { Nest }[F l a t t e n[T a b l e[\{\{w 1[\#[[i, 1]]], w 1[\#[[i, 2]]], w 1[\#[[i, 3]]}{\text { Saiful Marom }}
\end{aligned}
$$


]$, w 1[\#[[i, 4]]]\},\{w 2[\#[[i, 1]]], w 2[\#[[i, 2]]]$, w2 [\#[[i, 3$]]]$, w2 $[\#[[i, 4]]]\},\{w 3[\#[[i, 1]]]$, w3 [\#[[i, 2$]]]$, w3 [\#[[i, 3] ] ], w3 [\#[[ $i, 4]]]\},\{w 4[\#[[i, 1]]], w 4[\#[[i, 2]]], w 4[\#[[i, 3]]], w 4[\#[[i, 4]$ ]$]\},\{w 5[\#[[i, 1]]], w 5[\#[[i, 2]]], w 5[\#[[i, 3]]], w 5[\#[[i, 4]]]\}$, $\{w 6[\#[[i, 1]]], w 6[\#[[i, 2]]], w 6[\#[[i, 3]]], w 6[\#[[i, 4]]]\},\{w 7[$ $\#[[i, 1]]], w 7[\#[[i, 2]]]$, w7 [ \#[ [i,3]]] ,w7 [\#[[i, 4]] ]\}, \{w8[\#[[i $, 1]]]$, w8 [\#[[i,2] ] , w8 [\#[[i,3]]], w8 [\#[[i, 4] ] ] \} , \{i, Length $[\#$ ]$\left.\}], 1] \&,\left\{\left\{\left\{\mathrm{x} 1, \mathrm{y}^{1}\right\},\left\{\mathrm{x} 2, \mathrm{y}^{2}\right\},\left\{\mathrm{x} 3, \mathrm{y}^{3}\right\},\left\{\mathrm{x} 4, \mathrm{y}^{4}\right\}\right\}\right\}, \mathrm{n}\right] ;$

Manipulate $[$ vertices $=\operatorname{Karpet}[n,\{\{0,0\},\{1,0\},\{1,1\},\{0,1\}\}]$; Graphics $[\{$ Purple, Map [Polygon, vertices, 1$]\}],\{n, 0,7,1\}]$

Berikut hasil running program wolframs yang dibuat diperoleh :

Untuk $\mathrm{n}=0$

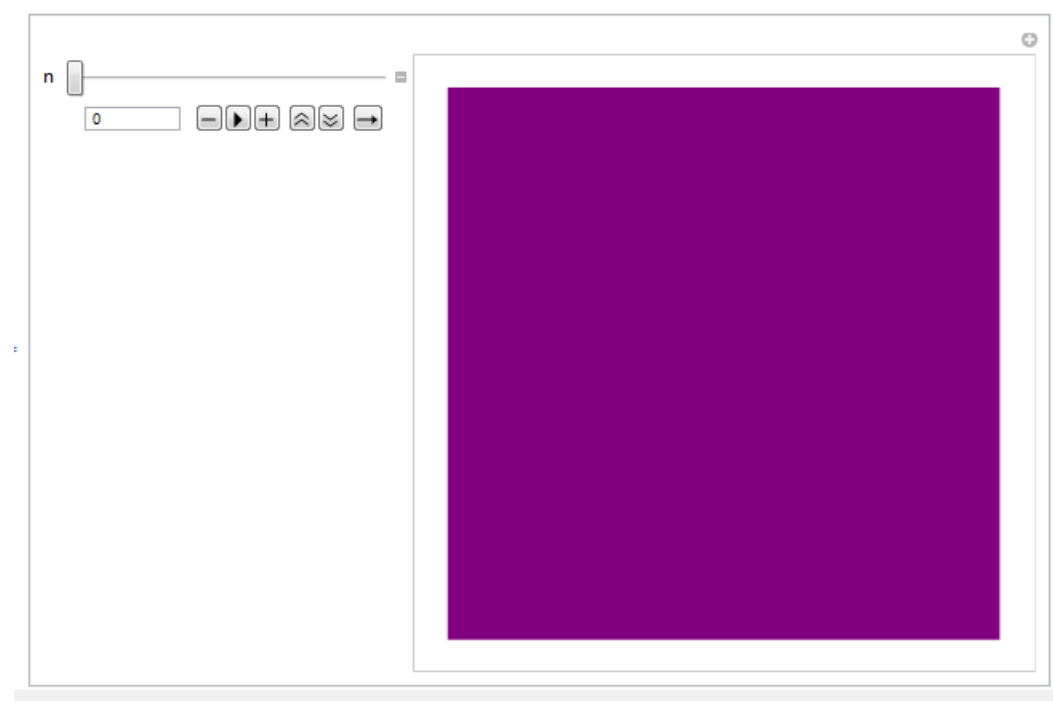

Untuk $\mathrm{n}=1$

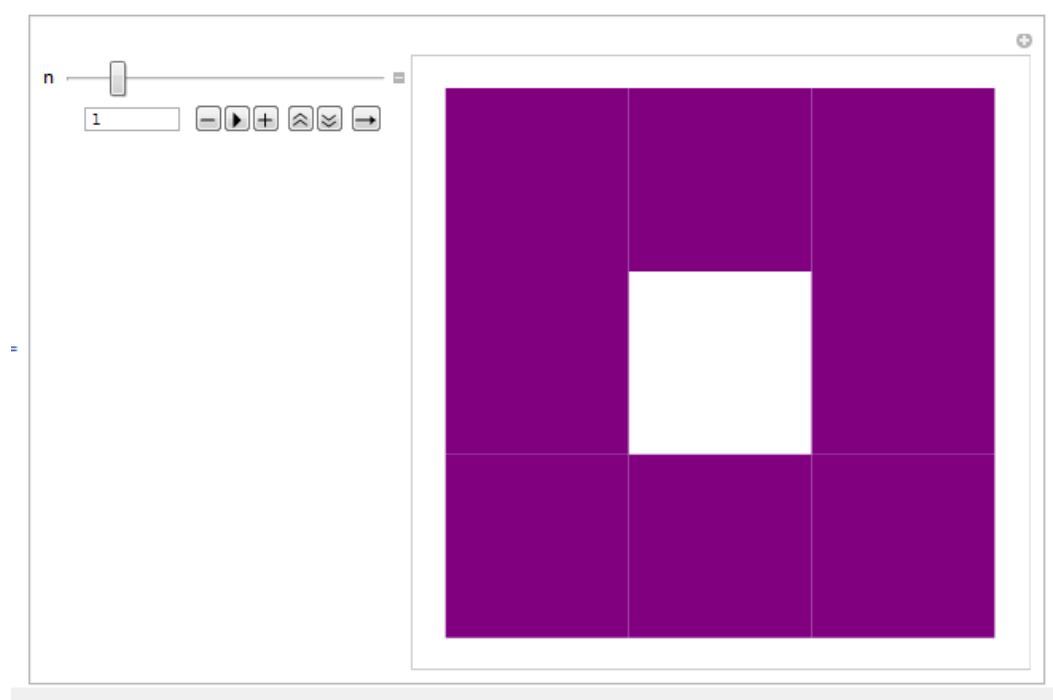


Untuk $\mathrm{n}=2$

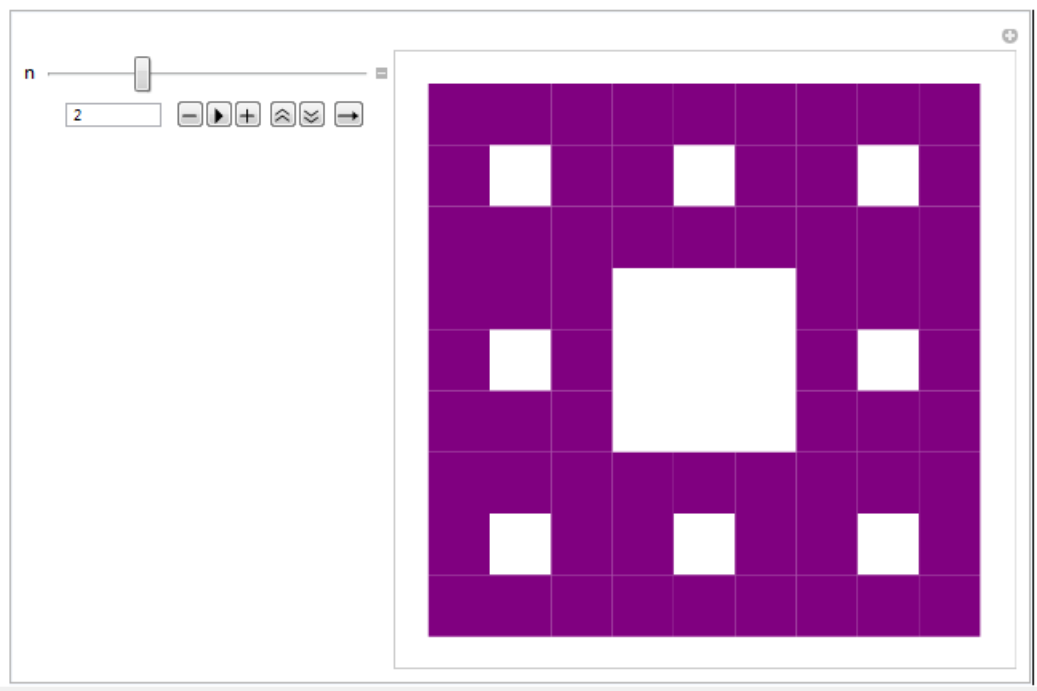

Untuk $\mathrm{n}=3$

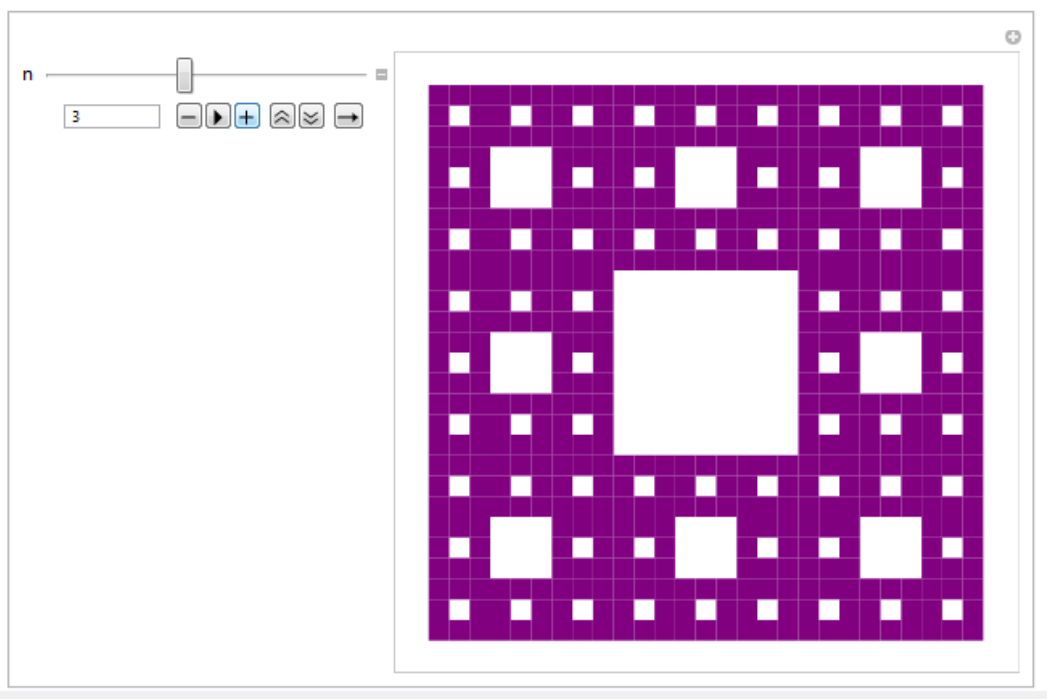

\section{Aplikasi Konsep Fraktal dalam Pembentukan Motif Batik}

Dengan menggunakan bantuan bahasa pemrograman berbasis wolframs mathematica ini maka kita dapat dengan mudah melihat bagaimana kondisi visualisasi dari hasil proses logika matematika yang dijalankan. Dalam matematika ada suatu konsep iterasi yakni Iterated Function System atau dikenal dengan istilah IFS. IFS adalah suatu metode yang digunakan untuk membuat sebuah fractal hasil dari IFS tersebut akan selalu membentuk fractal dengan hasil self similar.

Dalam matematika iterasi fungsi adalah object study yang mendalam dalam ilmu komputer, fraktal dan system dinamik fungsi iterasi adalah fungsi yang terdiri dengan dirinya sendiri, tak terhingga dalam proses yang di sebut iterasi dalam proses ini mulai dari beberapa nilai awal, kita harus menghitung hasil dan kemudian feed ini mengakibatkan fungsi sebgai masukan dan menghitung hasil dan mengulanginya berulang kali. Setiap fungsi dapat diiterasikan menggunakan 
konsep IFS tersebut sehingga dengan menggunakan bantuan program komputer maka dapat dihasilkan suatu motif tertentu yang sangat unik. Selanjutnya pada kajian ini penulis mengaplikasikan fungsi Lyapunov yang diiterasikan sehingga dengan menggunakan bantuan bahasa pemrograman akan dapat dihasilkan suatu motif yang nantinya akan dijadikan menjadi motif batik. Sebelumnya akan diberikan definisi mengenai fungsi lyapunov. Menurut Luenberger jika diberikan fungsi $\mathrm{V}: \mathrm{E} \subset \mathrm{R}^{\mathrm{n}} \rightarrow \mathrm{R}$ dan $\mathrm{x} \in \mathrm{E}$. Fungsi $\mathrm{V}$ terdefinisi pada $\mathrm{E}$ dan memuat $\mathrm{x}$ disebut fungsi Lyapunov jika memenuhi :

(i) Fungsi $\mathrm{V}$ kontinu dan memilki turunan pertama dari $\mathrm{V}$ yang kontinu.

(ii) $\mathrm{V}(\mathrm{x})$ memiliki titik minimum yang tunggal pada $\mathrm{E}$ dengan $\mathrm{V}(\mathrm{x}) \leq 0$ untuk setiap $\mathrm{x} \in \mathrm{E}$.

Dengan menggunakan bantuan bahasa pemrograman wolframs mathematica yaitu :

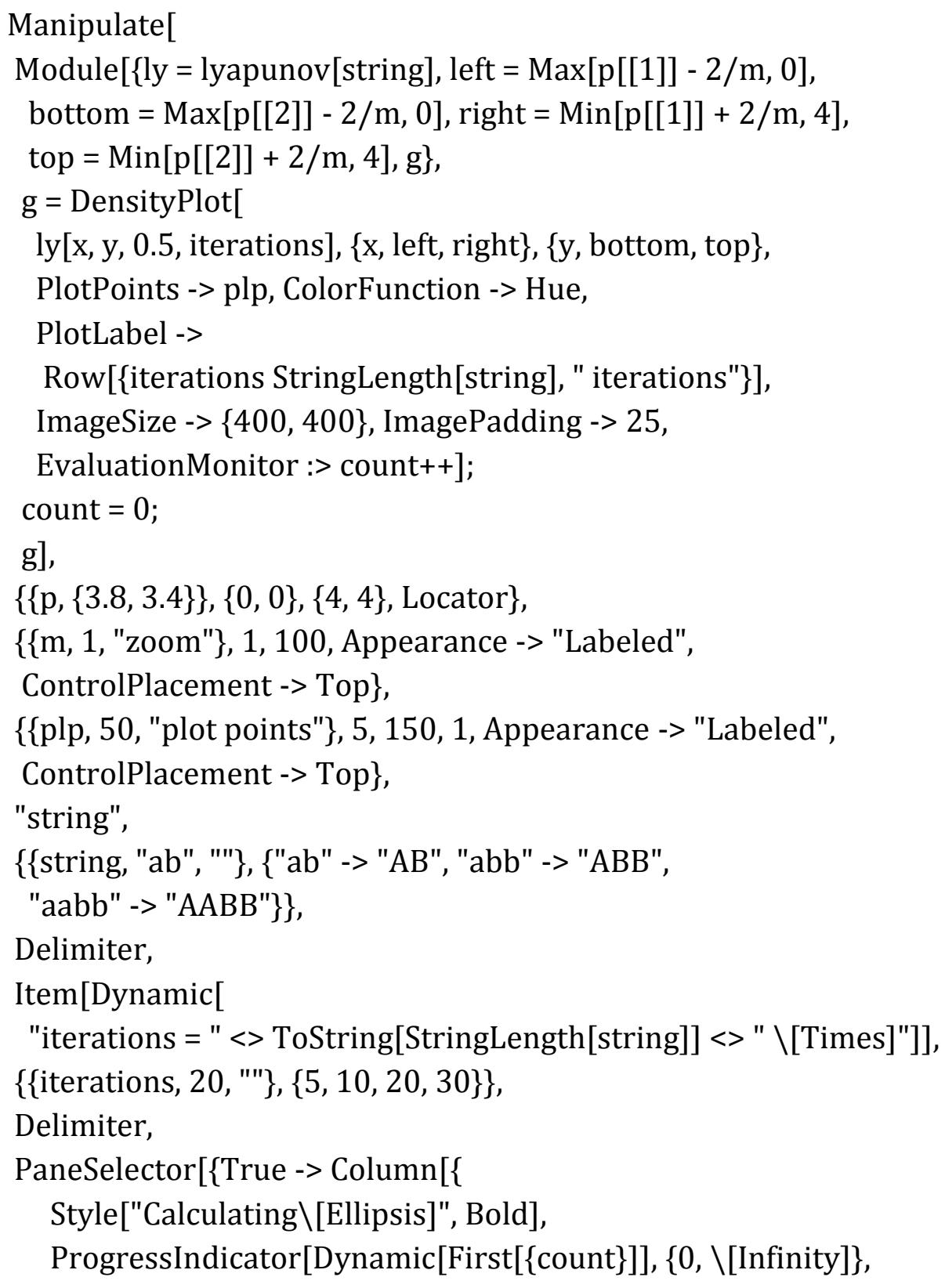


ImageSize -> Small]\}], False -> "'\}, Dynamic[count > 0]],

$\{\{$ count, 0$\}$, ControlType $->$ None $\}$,

AutorunSequencing $\rightarrow\{1,2\}$,

SynchronousUpdating $\rightarrow$ False,

TrackedSymbols :> $\{\mathrm{m}$, plp, string, iterations, $\mathrm{p}\}$,

ControlPlacement -> Left,

Initialization :>

lyapunov[str_] := lyapunov[str] =

ReleaseHold[Hold[

Compile $\left[\left\{\left\{\mathrm{a}, \_\right.\right.\right.$Real $\},\left\{\mathrm{b}, \_\right.$Real $\},\left\{\mathrm{x} 0, \_\right.$Real $\left.\},\left\{\mathrm{n}, \_I n t e g e r\right\}\right\}$,

Module $[\{$ sum $=0.0$, nextx $\}$,

Nest[Fold[Function $[\{\mathrm{x}, \mathrm{ch}\}$, next $=\operatorname{ch} \mathrm{x}(1-\mathrm{x})$;

sum $=\operatorname{sum}+\log [\operatorname{Abs}[\operatorname{ch}(1-2$ nextx $)]] ;$ nextx $]$, \#,

baseString] \&, x0, n];

sum/(n Length[baseString])]]

] /. \{baseString -> Characters[str] /. \{"a" ->a, "b" -> b\}\}]

),

Bookmarks $->\{$

"aabb 1" :> $\{\mathrm{m}=53.300000000000004$ ', plp = 93,

$\mathrm{p}=\left\{0.926^{\prime}, 3.91^{\prime}\right\}$, iterations $=20$, string $=$ "aabb" $\}$,

"aabb 2" :> $\left\{\mathrm{m}=23.5^{\prime}\right.$, plp = 89, $\mathrm{p}=\{3.758$ ', 0.905 $\}$,

iterations $=20$, string $=$ "aabb" $\}$,

"aabb 3" :> $\{\mathrm{m}=1$, plp = 75, $\mathrm{p}=\{1.992$ ', 2.015` $\}$,

iterations $=20$, string $=$ "aabb" $\}$,

"abb 1" :> $\{\mathrm{m}=14.100000000000001$ ', $\mathrm{plp}=79$,

$\mathrm{p}=\left\{3.844^{\prime}, 2.9250000000000003^{`}\right\}$, iterations $=20$,

string $=$ "abb" $\}$,

"abb 2" :> $\left\{\mathrm{m}=21.400000000000002\right.$, plp = 76, $\mathrm{p}=\left\{3.822^{\prime}, 2 \mathrm{~A}^{\prime}\right\}$,

iterations $=20$, string $=$ "abb" $\}$,

"abb 3" :> $\{m=11.4$ ', plp = 76, $p=\{3.404$ ', 3.0100000000000002 $\}$,

iterations $=20$, string $=$ "abb" $\}$,

"abb 4" :> $\left\{m=1, p l p=76, p=\left\{2\right.\right.$ ` $\left.^{\prime} 2.0100000000000002 `\right\}$,

iterations $=20$, string $=$ "abb" ,

"ab 1" :> $\left\{\mathrm{m}=56.37968282699589^{\circ}, \mathrm{plp}=50\right.$,

$p=\left\{3.8040000000000003 `, 3.3850000000000002^{`}\right\}$, iterations $=20$,

string = "ab" $\}$,

"ab 2" :> $\left\{\mathrm{m}=11.4\right.$, $\mathrm{plp}=75, \mathrm{p}=\left\{3.8^{\prime}, 3.4^{\prime}\right\}$, iterations = 20,

string $=" a b "\}$,

"ab 3" :> $\left\{\mathrm{m}=1, \mathrm{plp}=77, \mathrm{p}=\left\{1.992 `, 2.015^{`}\right\}\right.$, iterations = 20,

string $=$ "ab" $\}$

\}]

Selanjutnya hasil running dari bahasa pemrograman diatas adalah sebagai berikut: 


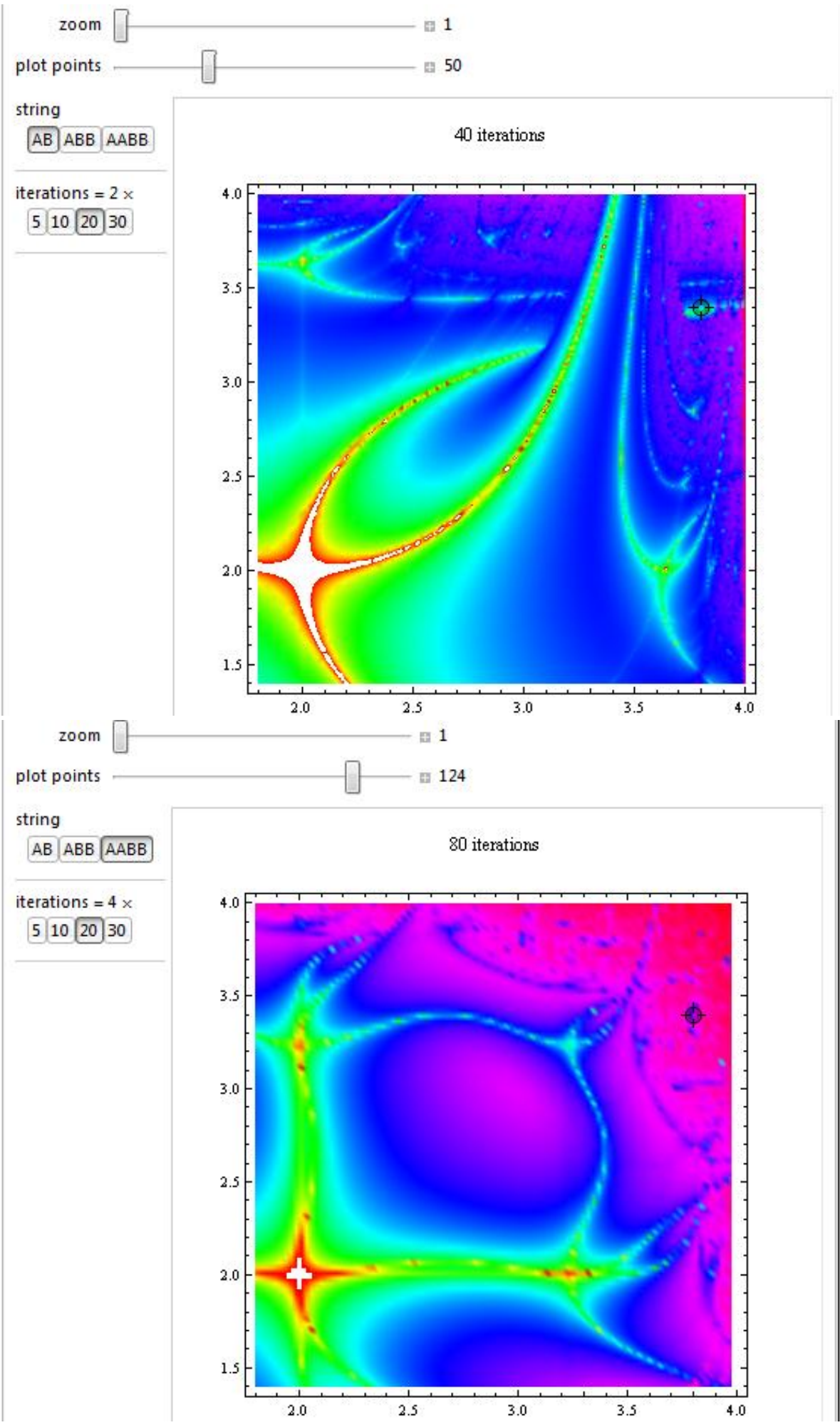

Untuk selanjutnya dengan mengubah iterasi dari fungsi tersebut maka akan didapatkan motif yang saling berbeda. Jadi, dengan menggunakan program tersebut kita dapat merangkai motif tersebut menjadi sebuah rangkain dari motif sebuah batik.

\section{Kesimpulan}


Matematika adalah suatu ilmu yang mempunyai tingkat abstraksi yang cukup tinggi sehingga untuk dapat membahami dari suatu konsep matematika terutama geometri khususnya geometri ftaktal diperlukan bantuan bahasa pemrogrman komputer. Dengan menggunakan konsep fraktal tersebut maka kita dapat dengan mudah untuk dapat mengeksplorasi suatu motif yang nantinya akan digunakan dalam pembuatan motif suatu batik.

\section{Daftar Pustaka}

[1] Barnsley, Michael F. 1993. Fractal Everywhere. Academic Press Proffesional. United States of America.

[2] Falconer, Kenneth. 2003. Fractal Geometry Mathematical Fondations and Applications, John Wiley and Sons, New York, USA.

[3] Havidsten , Michael. 2005. Geometry with geometry explorer. McGraw-Hill International.

[4] Http://id.wikipedia.org/wiki/Fraktal. diakses 7 Januari 2018.

[5] Luenberger, David G.,1979, Introduction to Dynamical Systems : Theory, Models, and Application, John Wiley and Sons, New York, USA.

[6] S, Roger Pressman. 2005. Software Engineering, A Practitioner's Approach. New York:McGraw-Hill. 